\title{
High Performance Liquid Chromatographic Method for Determination of Sildenafil Citrate (Viagra) in Pharmaceutical Formulation and Industrial Effluent Sample
}

\author{
Nief R. Ahmed \\ Department of Environmental \\ Technology \\ College of Environment \\ University of Mosul
}

\author{
Suhaib N. Lottfi \\ The State Company for Drug Industries \\ and Medical Appliances \\ Mosul-Iraq
}

(Received 8/10/2012;Accepted 28/1/2013)

\begin{abstract}
A simple, precise, rapid and accurate reversed-phase high performance liquid chromatographic method has been developed for the determination of sildenafil citrate in a pure form, pharmaceutical formulations and industrial effluent samples. Chromatography was carried out on supelco $\mathrm{L}_{7}$ reversed- phase column $(25 \mathrm{~cm} \times 4.6 \mathrm{~mm}), 5$ microns, using a mixture of methanol: water: triethylamine (630: $370: 2 \mathrm{v} / \mathrm{v} / \mathrm{v})$ and adjusted to $\mathrm{pH} 4.0$ with dilute phosphoric acid as a mobile phase at a flow rate of $1.0 \mathrm{ml} . \mathrm{min}^{-1}$.Uv detection was performed at $220 \mathrm{~nm}$ at ambient temperature $\left(25^{\circ} \mathrm{C}\right)$. The retention time for sildenafil citrate found to be 4.6 minutes. The calibration curve was linear $(\mathrm{r}=0.9998)$ over a concentration range from 10 to 70 $\mu \mathrm{g} / \mathrm{ml}$. Limit of detection (LOD) and limit of quantification (LOQ) were $60 \mathrm{ng} / \mathrm{ml}$ and 180 $\mathrm{ng} / \mathrm{ml}$ respectively. The method was validated for its linearity, precision and accuracy. The proposed method was successfully applied to the determination of sildenafil citrate in tablets and industrial effluent samples.
\end{abstract}

Keyword: HPLC, Sildenafil citrate, Viagra, Pharmaceutical preparations, Industrial effluent.

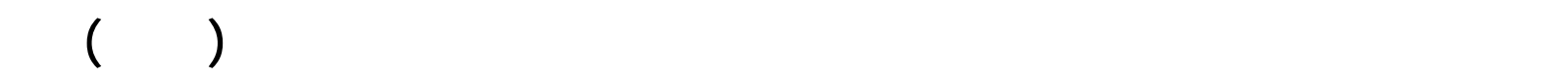 مستحضراله الصيدلنية في الميل الصناعية الملرححة}

\section{الملأص}

قم ظوير طريقة كروماتوغرافيا للسائ عالي الأداء لقدير للسلدينافلستريت بحالته القية وفي بعض مستحضرالته الصيدلانية وفي الميله الصناعية الططروحة. تتميز الطريقة بالبسلة والدقة وللسرعة والضط

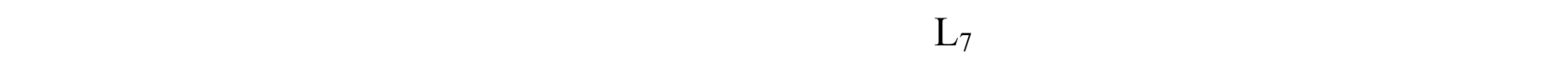
ناقلاً بنسبة (2:370:630) حجم/ حجم/ حجم. وقم تشبيت الداله الحلمضيه عند 4.0 بولطة حلمض الفنفوريك 
المخف وبسرعة جريلن 1 مل/ققيقة ولستخدلم مكشف الأشعة فوق البفسجية عند الطول الموجي 220 نانوميتر

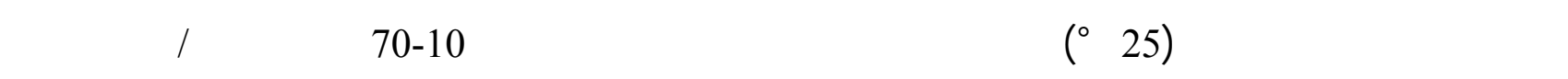

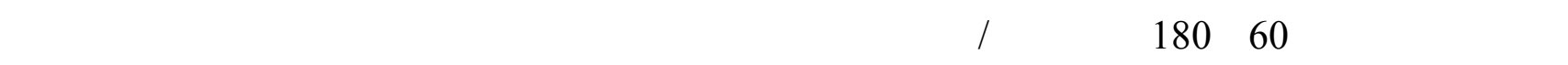
والضط والدقة ولستخمت الطريقة بنجاح لقدير السلدينافلستريت في الأقراص الدوائية وفي الميل الصناعية المطروحة.

\section{INTRODUCTION}

Sildenafil citrate is chemically known as 1-[[3-(6,7-dihydro-1-methyl-7-oxo-3-propyl-1H pyrazolo [4,3-d] pyrimidine-5-yl)-4-ethoxyphenyl]sulfonyl]-4-methylpiperazine citrate is popularly known as viagra, and has the following structural formula (Boolell et al., 1996):

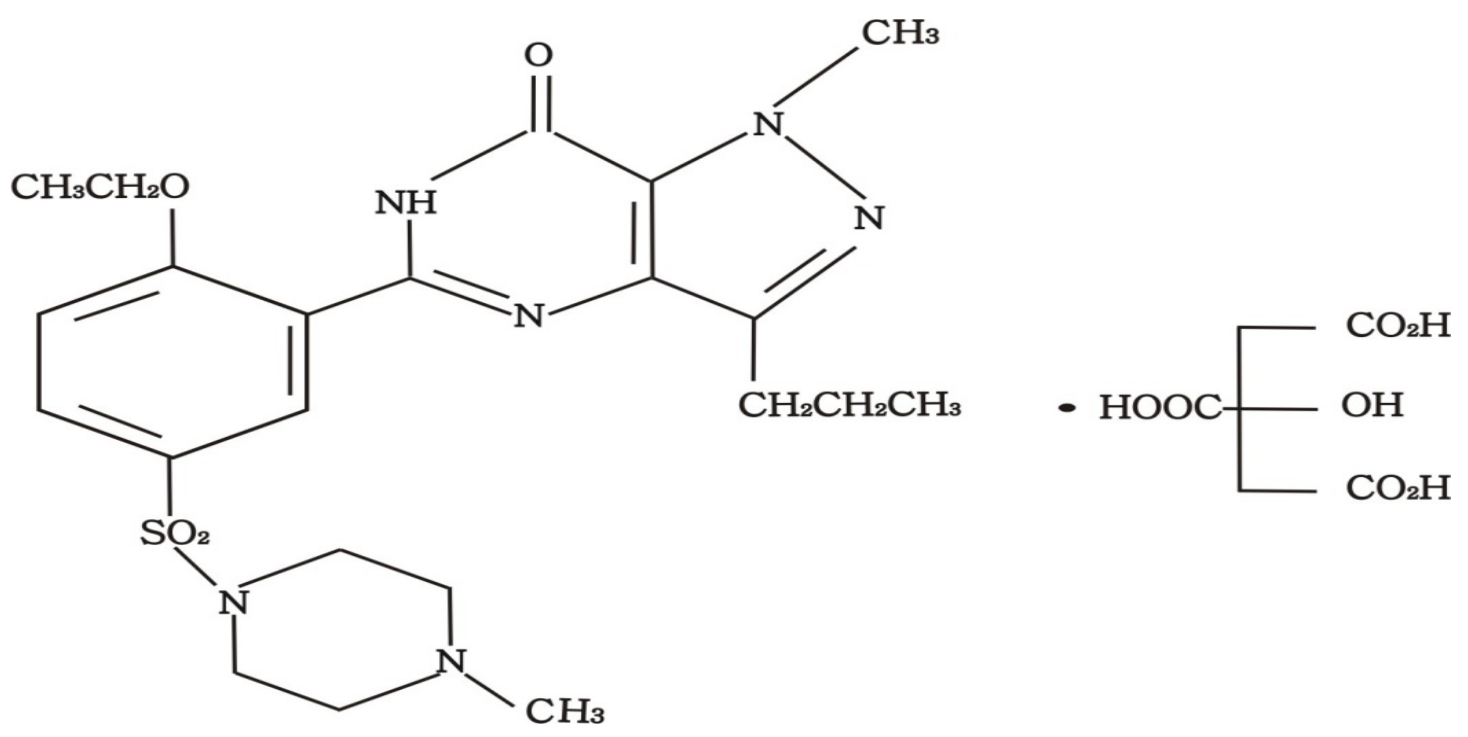

Sildenafil citrate is a therapy used for erectile dysfunction by acting as a selective inhibitor of cyclic guanosine mono phosphate (cGMP) -specific phosphodiesterase type 5 (PDE5). (Amin and EL-Bashbeshy., 2001, and Hassan et al., 2006). Sildenafil has no direct relaxant effect on isolated human corpus cavernosum, but enhances the effect of nitric oxide (NO) by inhibiting phosphodiesterase type 5 (PDE5), which is responsible for the degradation of (cGMP) in the corpus cavernosum. When sexual stimulation causes local release of NO, inhibition of PDE5 by sildenafil, causes increased levels of cGMP in the corpus cavernosum, resulting in smooth muscle relaxation and inflow blood to the corpus cavernosum (Kim et al., 1991; Bush et al., 1992). Few reports have been described for the determination of sildenafil citrate, these include Uv spectrophotometry (Ashok et al., 2010) extractive spectrophotometry based on the formation of ion-pair of sildenafil with bromocresol purple, and brilliant blue (Harikrishna et al., 2008), orange $\Pi$ and eriochrome black-T (Reddy et al., 2002) bromo-cresol green and chromoxane cyanine R (Dinesh et al., 2002). Spectrophotometric method based either on the 
formation of yellow chromogen with sodium nitropruside and hydroxylamine or formation of violet colored chromogen with metol and iodine (Rao et al., 2003), sildenafil citrate also determined spectrophotometrically using p-chloranil and accelerated by hydrogen peroxide (Weinert et al., 2008), flow injection analysis (Altiokk et al., 2001), resonance ray light scattering method (Liu et al., 2006), electro chemistry. (Othman et al., 2004 and Hassan et al., 2006), electro spray tandem mass spectrometry (Abdel-Hamid 2006), high performance liquid chromatography (Daraghmeh et al., 2001; Tracqui et al., 2003 ; Nagaraju et al., 2003; Amar et al., 2011), and (HPTLC) (Ashutosh et al., 2012). In order to minimize batch -to- batch variation there is an immense need for developing a rapid, sensitive and validated analytical method for day-to- day analysis of the drug in pharmaceutical dosage forms.

\section{EXPERIMENTAL}

\section{Apparatus}

The chromatographic apparatus is a Shimadzu HPLC model LC-20AT with UV detector model SPD-20A and $\mathrm{L}_{7}$ Supelco column $(25 \mathrm{~cm} \times 4.6 \mathrm{~mm}), 5$ microns. HPLC conditions are given in Table (1).

\section{Table 1 : Conditions of HPLC method}

\begin{tabular}{|l|l|}
\hline Column & $\mathrm{L}_{7}$ \\
Wavelength & $220 \mathrm{~nm}$ \\
Injection volume & $20 \mu \mathrm{l}$ \\
Flow rate & $1.0 \mathrm{ml} / \mathrm{min}$ \\
Temperature & Ambient $\left(25^{\circ} \mathrm{C}\right)$ \\
Retention time & $4.6 \mathrm{~min}$ \\
Mobile phase(v:v:v) & Methanol \\
& $: \mathrm{H}_{2} \mathrm{O}:$ Triethylamine \\
& $630: 370: 2$ \\
\hline
\end{tabular}

\section{Chemicals and reagents}

All chemicals used were of analytical or pharmaceutical grade and deionized water was used throughout.

Sildenafil citrate stock solution was prepared by dissolving accurately weighed quantity of $100 \mathrm{mg}$ of the drug in $100 \mathrm{ml}$ of methanol (final concentration, $1 \mathrm{mg} / \mathrm{ml}$ ). From this stock solution, standard solution containing $100 \mu \mathrm{g} / \mathrm{ml}$ sildenafil citrate was prepared by suitable dilution of the stock solution with methanol.

\section{Recommended procedure}

A series of standard solutions containing $10-70 \mu \mathrm{g} / \mathrm{ml}$ of sildenafil citrate and the sample solution of pharmaceutical preparation were applied, respectively. $20 \mu 1$ aliquot of each solution was injected into the column in a duplicate and the chromatograms were recorded. Calibration graph was constructed by plotting the mean peak area versus concentration of 
sildenafil citrate. The concentration of the unknown was read from the calibration graph or calculated from the regression equation derived from the concentration and peak area data.

\section{Procedure for pharmaceutical preparations (tablet):}

To minimize a possible variation in the composition of the tablet, the mixed content of 10 tablets, were weighed and grounded, then the powder equivalent to $50 \mathrm{mg}$ of sildenafil citrate was stirred well with $100 \mathrm{ml}$ methanol for $30 \mathrm{~min}$. and then filtered through a Whatman No. 42 filter paper. The filtrate was made up to $250 \mathrm{ml}$ with methanol in a volumetric flask and the filtrate solution was further diluted to get $30 \mu \mathrm{g} / \mathrm{ml}$ and then determination of sildenafil citrate as described under recommended procedure.

\section{Procedure for industrial waste water}

To demonstrate the practical applicability of the proposed method, industrial waste water samples from the state company for drug industries and medical appliances, Mosul-Iraq, were collected in polyethylene container cleaned with nitric acid, and filtered through Whatman No.41 filter paper. Filtered samples were stored at $4 \mathrm{C}^{\circ}$ until analyzed by spiking with the concentrations ranging from $20-60 \mu \mathrm{g} \cdot \mathrm{ml}^{-1}$ of sildenafil citrate and aliquot of this solution was treated as described above for recommended procedure.

\section{RESULTS AND DISCUSSION}

The chromatographic conditions were adjusted in order to provide a good performance of the assay. The method involved a mobile phase consisting of methanol: water: triethylamine 630:370:2 (v/v/v), adjusted to $\mathrm{pH} 4$ by adding phosphoric acid (5 M), accomplished at $220 \mathrm{~nm}$. The retention time was 4.6 minutes at a flow-rate of $1.0 \mathrm{ml} / \mathrm{min}$ and the injection volume was $20 \mu$. The mobile phase was chosen after several trials with other solvent combinations. Mobile phase selection was based on peak parameters (symmetry, tailing), run time, ease of preparation and cost. Fig.1 shows a typical chromatogram obtained from the analysis of a standard of sildenafil citrate using the proposed method. Under the described experimental conditions, the analyte peaks were well-defined and free from tailing. 


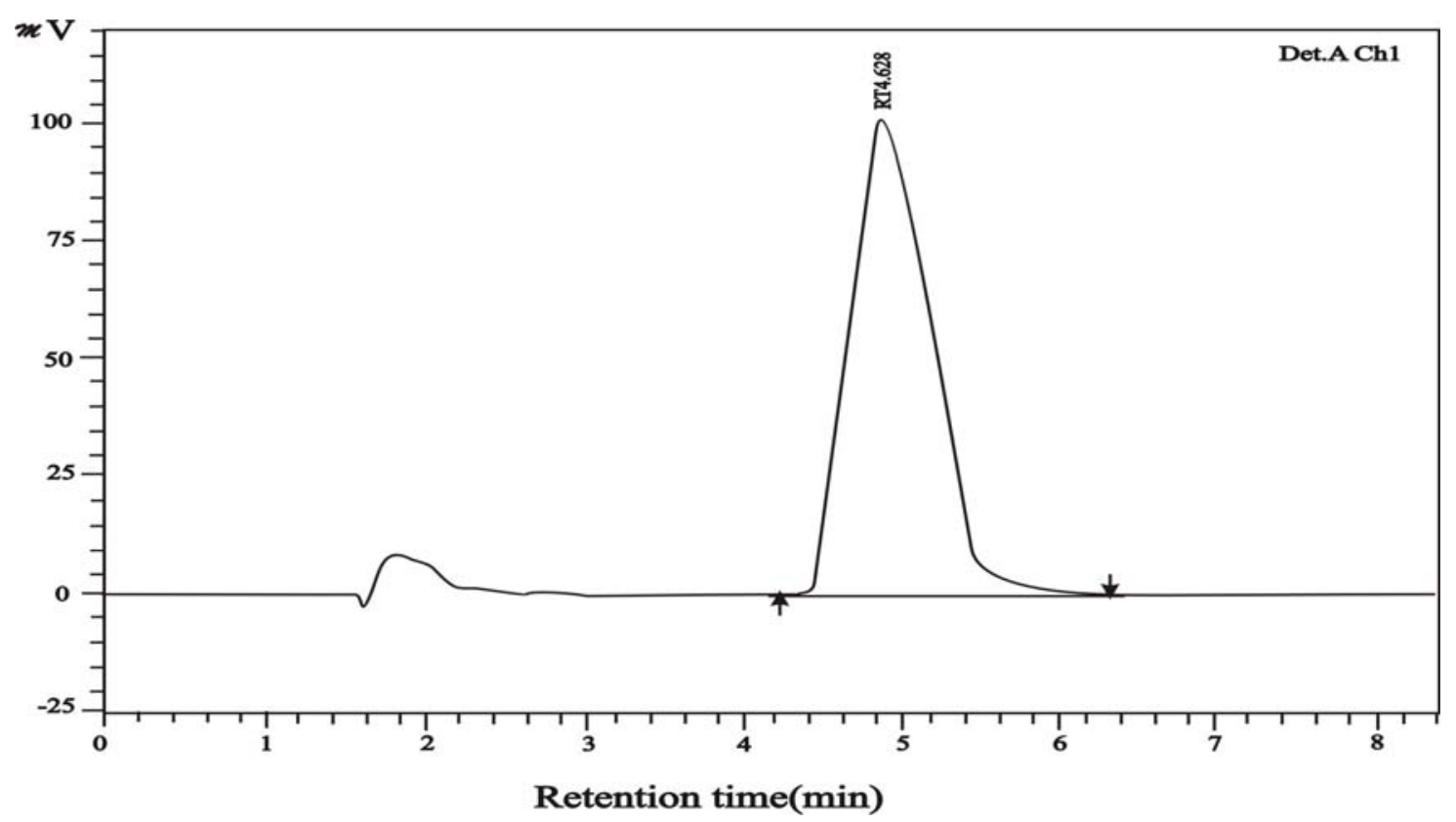

Fig. 1 : Typical chromatogram (sildenafil citrate 10 $\mathrm{\mu g} / \mathrm{ml}$ ).

Sildenafil citrate was determined by measuring the peak area. A plot of peak area against concentration gave a linear relationship $\left(\mathrm{r}^{2}=0.999\right)$ over the concentration range $10-70 \mu \mathrm{g} / \mathrm{ml}$. Using regression analysis, the linear equation $\mathrm{Y}=21996 \times-99461$ was obtained where $\mathrm{Y}$ is the mean peak area and $X$ is the concentration in $\mu \mathrm{g} / \mathrm{ml}$ (Fig. 2).

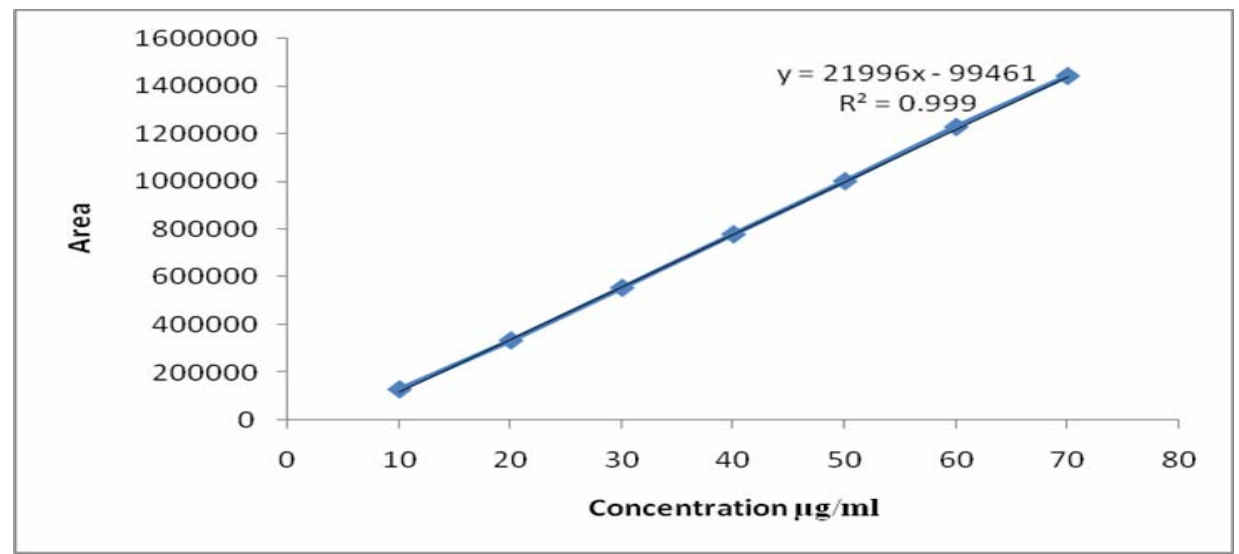

Fig. 2: Calibration curve of sildenafil citrate

\section{Determination of limit of detection and limit of quantification ( sensitivity )}

A series of dilute solutions were prepared in the rang of $0.1 \%, 0.5 \%$ and $1 \%$ of the assay concentration $(30 \mu \mathrm{g} / \mathrm{ml})$ using the standard solutions. $20 \mu \mathrm{l}$ of each of the above solutions were injected in 6 times and the area were calculated due to sildenafil citrate peak. The standard deviation for the 6 injections for each concentration was calculated. The standard 
deviation at concentration zero was calculated and this value was used for the calculation of the limit of detection and limit of quantification. The limits of detection (LOD) and quantification (LOQ) were calculated using the following formulae: $\mathrm{LOD}=(3.3 \sigma / \mathrm{s})$ and $\mathrm{LOQ}=(10 \mathrm{\sigma} / \mathrm{s})$ where $\sigma$ is the standard deviation of the response and $\mathrm{s}$ is the slope of the regression line (Laxman et al., 2011). Limit of detection (LOD) and limit of quantification (LOQ) were found $60 \mathrm{ng} / \mathrm{ml}$ and $180 \mathrm{ng} / \mathrm{ml}$, respectively. The results indicate that the method was sensitive enough to detect a concentration of $60 \mathrm{ng} / \mathrm{ml}$ and able to quantify at a concentration of above $180 \mathrm{ng} / \mathrm{ml}$.

\section{Precision and accuracy}

The precision of the calibration graph was established by carrying out the analysis of sildenafil citrate $(n=6)$ using the proposed method. The low value of standard deviation showed that the method was precise. The results obtained are presented in Table 2. To ensure the reliability and accuracy, recovery studies were carried out at five different levels. The results of recovery studies were found to be accurate, mean recoveries being $100.653 \pm 1.9(n=6)$ as shown in Table 2.

\section{Table 2 : Precision and accuracy}

\begin{tabular}{|c|c|c|}
\hline $\begin{array}{c}\text { Concentration of } \\
\text { sildenafil citrate, } \\
\boldsymbol{\mu g} / \mathbf{m l}\end{array}$ & Recovery ( \%) & RSD ( \% ) \\
\hline 10 & 101.4 & 0.9 \\
20 & 100.5 & 0.85 \\
30 & 101.9 & 1.1 \\
40 & 99.875 & 1.06 \\
60 & 99.5 & 0.8 \\
\hline Mean(n=6) & 100.635 & 0.942 \\
\hline
\end{tabular}

\section{APPLICATIONS}

The proposed method was successfully applied to the assay of sildenafil citrate in tablet and industrial waste water sample. The result of analysis of pharmaceutical formulation (Table 3) reveals that there is a close agreement between the results obtained by the proposed method and label claim, and the results of the industrial waste water samples. Table 4 shows that the recovery values obtained were close to $100 \%$.

Table 3 : Determination of sildenafil citrate in tablets.

\begin{tabular}{|c|c|c|c|}
\hline $\begin{array}{c}\text { Pharmaceutical } \\
\text { formulations }\end{array}$ & $\begin{array}{c}\text { Label amount } \\
\text { (mg) }\end{array}$ & Found (mg) & Recovery ( \%) \\
\hline Nanagra tablet (NDI) & 25 & 25.1 & 100.4 \\
& 50 & 49.95 & 99.9 \\
& 100 & 99.88 & 99.88 \\
\hline
\end{tabular}

$\star$ Mean of six determinations. 
Table 4: Determination of sildenafil citrate in industrial waste water samples

\begin{tabular}{|c|c|c|}
\hline Water sample & $\begin{array}{l}\text { Sildenafil citrate }(\mu \mathrm{g} / \mathrm{ml}) \star \\
\text { Taken }\end{array}$ & Recovery (\%) \\
\hline Industrial waste water & $\begin{array}{lc}20 & 20.00 \\
40 & 40.40 \\
60 & 60.36\end{array}$ & $\begin{array}{l}100.0 \\
101.0 \\
100.6\end{array}$ \\
\hline
\end{tabular}

$\star$ Mean of ten determinations

\section{CONCLUSION}

In this study, a simple, rapid, accurate HPLC method was developed and validated for the determination of sildenafil citrate in tablets and industrial waste water samples. The method was selective using $\mathrm{L}_{7}$ analytical column and applicable to pharmaceutical preparations. Thus, the developed method is recommended for control throughout the entire manufacturing process of drugs as well as quality control of the finished product in view of its high recovery and precision.

\section{ACKNOWLEDGMENTS}

The first author (Nief R. Ahmed) wishes to express gratitude to his former company[the state company of drug industries and medical appliance (NDI)] (Nineveh - Iraq) for providing gift sample of sildenafil citrate standard material and pharmaceutical preparations (tablet) and for permission and facilities to carry out the research work.

\section{REFERENCES}

Abdel-Hamid, M.E. (2006). Determination of sildenafil, tadalafil, and vardenafil in tablets and adulterated herbal products by ESI-MS-MS. J. liq. Chromato. Related Technol., 29(4), 591-603.

Altiokk, G.; Atkosar, Z.; Sener, E.; Tuncel, M. (2001). FIA of sildenafil citrate using UV-detection. J. Pharm. Biomed . Anal., 25(2), 339-342.

Amar, M.B.; Nesrine, T.L. (2011). Stability indicating methods for the determination of sildenafil citrate in the presence of its degradation product. Intern. J. Compreh. Pharm. 2(7), 1-6.

Amin, A.S.; EL-Bashbeshy, A.M. (2001). Utility of certain $\sigma$ and $\pi$ acceptors for spectrophotometric determination of sildenafil citrate (viagra). Mikrochim. Acta, 137, 63-69.

Ashok, K. ; Gaurav, R; Gaurav, S.; Atul, S. (2010). To Develop Uv spectrophotometric method for the estimation of sildenafil citrate in bulk and tablet. IJPRD, 2(7), 12.

Ashutosh, P.; Gunjan, A.; Bhavin, C.; Nishit, P.; Jagadish, K. (2012). Development and validation of HPTLC method for simultaneous estimation of sildenafil citrate and dapoxetine hydrochloride in their combined tablet dosage. IJPRBS, 1(2), 236-246.

Boolell, M.; Allen, M.J.; Ballard, S.A.; Gepi-Attee, S.; Muirhead, G.J.; Naylor, A.M.; Osterloh, I.H.; Gingell, C. (1996). Sildenafil: an orally active type 5 cyclic GMP- 
specific phosphodiesterase inhibitor for the treatment of penile erectile dysfunction. Int. J. Impot. Res. 8 (2), 47-52.

Bush, P.A.; Aronson, W.J.; Buga, G.M.; Rajfer, J.; Ignarro, L.J. (1992). Nitric oxide is a potent relaxant of human and rabbit corpus cavernosum. J. Urol., 147, 1650-1655.

Daraghmeh, N.; Al-Omari, M.; Badwan, A.A.; Jaber, A.M. (2001). Determination of sildenafil citrate and related substances in the commercial products and tablet dosage form using HPLC. J. Pharm. Biomed. Anal, 25(2), 483-492.

Dinesh, N.D.; Nagaraja, P.; Gowda, N.M.; Rangappa, K.S. (2002). Extractive spectrophotometric method for the assay of sildenafil citrate (viagra) in pure form and pharmaceutical formulation . Talanta, 57(4), 757-764.

Harikrishna, K.; Nagaralli, B.S.; Seetharamappa, J. (2008). Extractive spectrophotometric determination of sildenafil citrate (viagra) in pure and pharmaceutical formulations. J. Food and Drug Analysis, 16(1), 11-17.

Hassan, S.M.; Elnemma, M.; Wagiha, H.; Ayman, H. (2006). Continuous potentiometric montoring of viagra (sildenafil) in pharmaceutical preparations using novel membrane sensors. J. Appl. Electrochem., 36(2), 139-146.

Kim, N.; Azadzoi, K.M.; Goldstein, I.; Tejada, S. (1991). A nitric oxide-like factor mediate non- adrenergic non-cholinergic neurogenic relaxation of penile corpus cavernosum smooth muscle. J. Clan. Invest., 88, 112-118.

Laxman, S. ; Bala, P.; Anil, M.; Nandini, P.; Nancy, P. (2011). Development and validation of HPLC method for quantification of phytoconstituents in phyllanthus emblica. J. Chem. Pharm. Res., 3(4), 937-944.

Liu, S.; Fan, L.; Hu, X. ; Liu, Z.; Shan, L. (2006). Resonance ray light- scattering method for determination of sildenafil citrate in pharmaceutical formulation using Evans blue. Anal. Sci., 22, 819-823.

Nagaraju, V.; Sreenath, D.; Rao, J.; Rao, R. (2003). Separation and determination of synthetic impurities of sildenafil (viagra) by reversed-phase high- performance liquid chromatography. Anal. Sci. 19, 1007-1011.

Othman, A.M.; Rizk, N.M.; Elshahawi, M.S. (2004). Polymer membrane sensors for sildenafil citrate (viagra) determination in pharmaceutical preparations. Anal. Chem. Acta. 515(2), 303-309.

Rao, P.V.; Sagar, G.V.; Sastry, B.S. (2003). Visible spectrophotometric methods for the determination of sildenafil in pharmaceutical formulations. Indian J. Pharm. Sci., 65, 73-75.

Reddy, M.N.; Murthy, T.K.; Rao, Y.S.; Sankar, D.G. (2002). Spectrophotometric determination of sildenafil citrate in pharmaceutical dosage forms. Indian J. Pharm. Sci. 64, 253-259

Tracqui, A.; Ludes, B. (2003). HPLC-MS for determination of sildenafil citrate (viagra) in biological fluids. Application to the salivary excretion of sildenafil after oral intake. J. Anal. Toxicol., 27(2), 88-94.

Weinert, P.L.; Pezza, L.; Pezza, H.R. (2008). Spectrophotometric determination of sildenafil citrate in pharmaceutical formulations. Quim. Nova. 31(5), 1112-1116. 